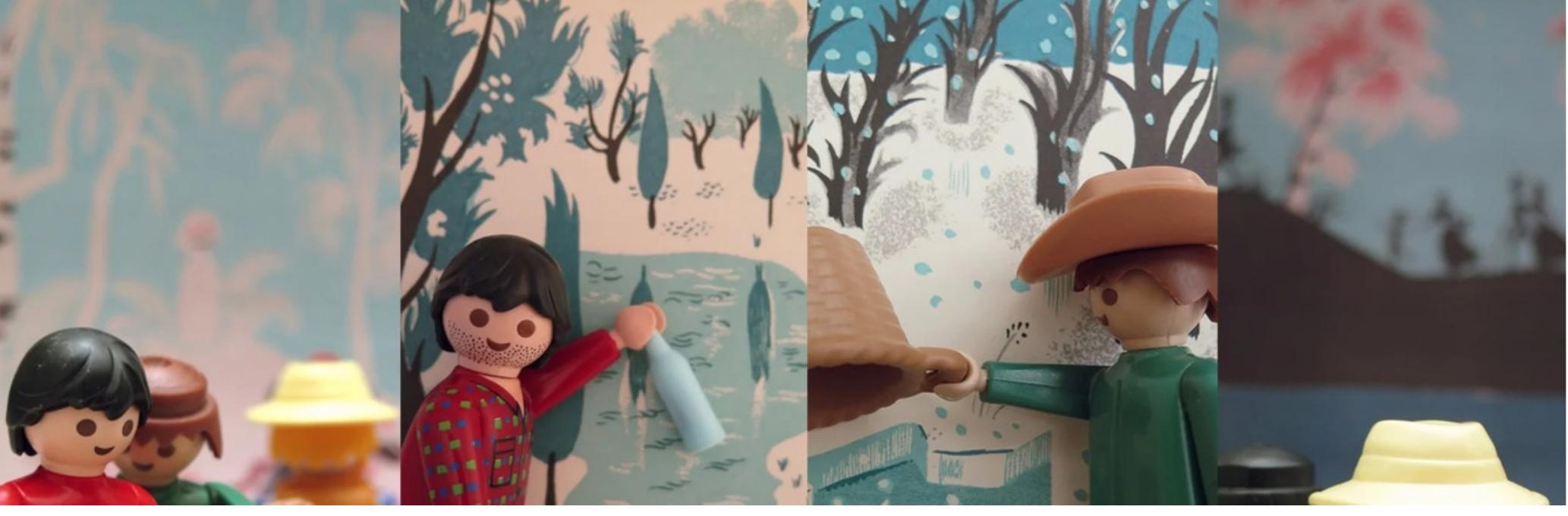

\title{
Indebted Meritocracy
}

$\begin{aligned} \text { Authors: } & \text { Sol Minoldo } \\ \text { Submitted: } & \text { 15. May } 2020 \\ \text { Published: } & 25 . \text { May } 2020 \\ \text { Volume: } & 7 \\ \text { Issue: } & 3 \\ \text { Affiliation: } & \text { El Gato y La Caja Journal. Buenos Aires, Argentina. } \\ \text { Languages: } & \text { English } \\ \text { Keywords: } & \text { Meritocracy, Meritocracia, El Gato y La Caja, journal project. } \\ \text { Categories: } & \text { Life Sciences } \\ \text { DOI: } & 10.17160 / \text { josha.7.3.674 }\end{aligned}$

\section{Abstract:}

A meritocracy is a society in which success and failure belong to those who 'deserve' them. What you get depends directly on the decisions you make and on archiving the right balance between responsibility and audacity. Yet, a key point is frequently overlooked: identical circumstances, means, and opportunities must be guaranteed for meritocracy to make sense. In this article, Sol Minoldo highlights the danger of the reverse the logic, that is, assuming that the different achievements are a reliable proof that some made more effort than others, and discusses what a higher performance might actually reflect.

\section{JOSHA Jouma ossencea Humanities and Arts}




\title{
Indebted meritocracy
}

\section{BY SOL MINOLDO}

llustrator: Cristina Potenza

Original Title: La meritocracia te la debo

Date of publication: 9/10/2017

Link to original text: https://elgatoylacaja.com.ar/la-meritocracia-te-la-debo/

\begin{abstract}
A meritocracy is a society in which success and failure belong to those who 'deserve' them. What you get depends directly on the decisions you make and on archiving the right balance between responsibility and audacity. Yet, a key point is frequently overlooked: identical circumstances, means, and opportunities must be guaranteed for meritocracy to make sense. In this article, Sol Minoldo highlights the danger of the reverse the logic, that is, assuming that the different achievements are a reliable proof that some made more effort than others, and discusses what a higher performance might actually reflect.
\end{abstract}

Sometimes we remember a story and have no idea where or when we first heard it. Millennia before the internet, moral anecdotes were already mutated in each iteration thanks to the free version of orality and the most used source of the story: 'the friend of a friend'. It was in this way that the story of this family from Córdoba came to me.

Once upon a time, there was a gentleman in his 70 s with three rather cheeky children. One day they stood up to him to divide their inheritance while he was still alive, 
because they had no time to wait for him to die. The guy agreed and divided his estate into three equal parts.

Legend has it that one of them went out to party with a check in hand and was never heard from again until the last penny was spent. The middle brother buried the money in the courtyard of the house and, the day he dug it up, inflation ruined him. The third one invested the money and in a few years he had made a fortune. Quick and dirty moral: what you get depends directly on the decisions you make, on the right balance between responsibility and audacity. In the face of identical circumstances and with the same means, it will be better for the one who puts his energy and his wit into it than for the one who is half slow or directly a hopeless case.

This idea is sometimes presented to us as a confirmation that everything is fair and divine. Because a world in which effort is rewarded is one in which the good win, understood as those who fight it, do not take shortcuts or sunbathe on the sidelines. But it also pushes reality to be a little better, because with its promise of prizes and punishments it encourages us to prefer effort. And even more, it is a world in which your destiny is in your hands, it depends on you, on what you do. It is to be determined, to put your energy into it and that is it! That's how nice it sounds to 'live in a meritocracy'.

\section{A meritocracy is a society in which success and failure belong to those who} 'deserve' them. And that's because rewards and punishments are distributed in a 'fair' proportion to the effort of each. It is important to clarify that when we speak of meritocracy we are generally speaking of ONE FORM of meritocracy in particular. On the one side, one in which rewards and punishments are forms of distribution of wealth. And on the other side, one in which what is defined as 'effort', as something valuable or virtuous ('deserving' of something good), is a certain way of understanding it, and which tends to be identified with 'work', 'study' and 'audacity' (specifically, in economic behaviour). 
Journal of Science, Humanities and Arts

\section{The 'necessary condition' that we often overlook}

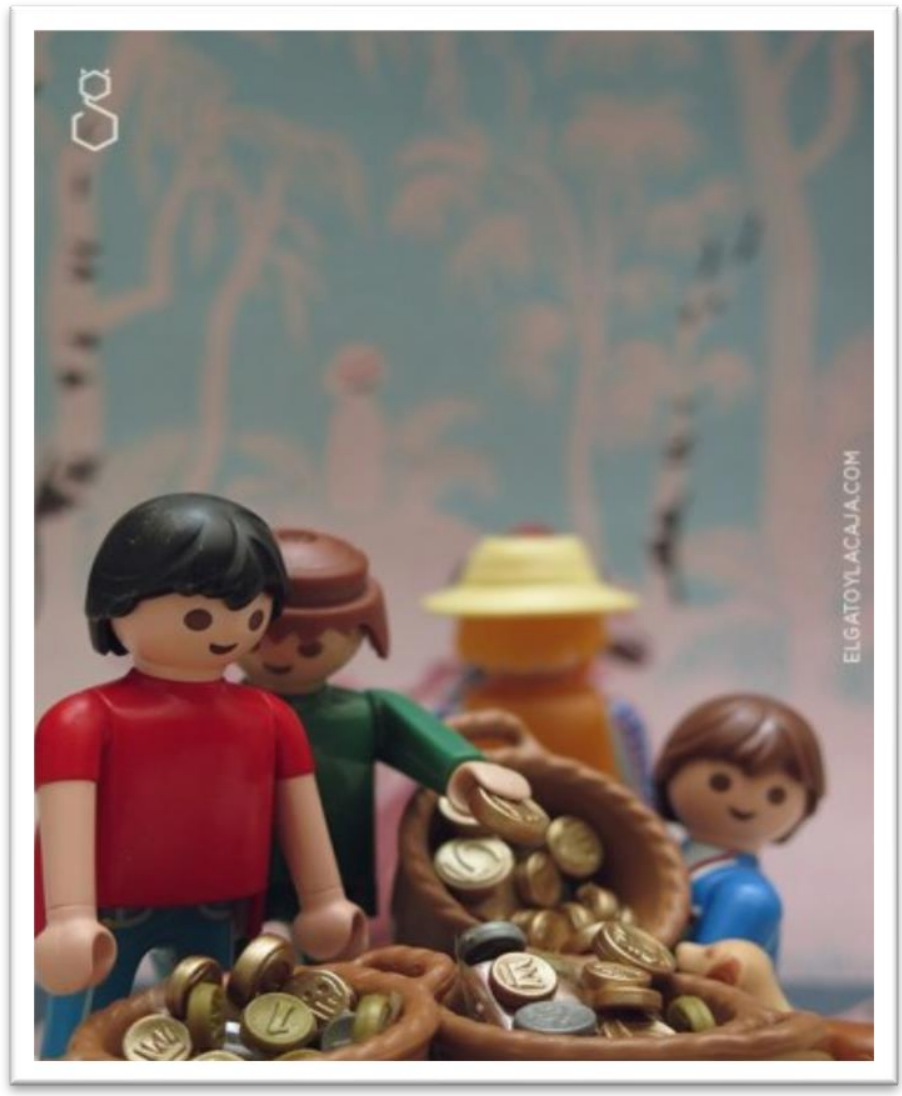

Let's go back to the legend of the brothers from Córdoba, that clear example that 'individual performance makes the difference'. One thing is important not to overlook: for the difference in achievement to be explained by what each did, it was necessary for all three to have 'identical circumstances, means, and opportunities'. Things would have been quite different if, for example, one of the brothers had received twice as much inheritance as the other; or if one had had much more expense because of a chronic illness; or if one had simply been lucky, crossing paths by chance with opportunities that his brothers did not. We can even imagine that one of the brothers in particular had friends who got him a great business... and so we could go on until we filled a whole book.

If the IDENTICAL circumstances, means and opportunities are fundamental conditions for the difference to depend on each one, and if those conditions might not actually exist, it is dangerous (and fallacious) to reverse the logic and assume that the different achievements are reliable proof that some made more effort than others.

It's just as tricky to insist that 'living in a meritocracy will depend on our belief in it and in the value of effort', because none of that will lead to those key conditions being met if, to achieve the same, some have to work much harder than others. Because, beware, that circumstances do not absolutely determine your possibilities, 
and that with effort you can achieve more than without it, is not synonymous with meritocracy. Thus, there will always be a Roberto or a Marta who, despite growing up in the slums, 'graduated as a doctor with the best average of the faculty, while selling cakes and taking care of his five brothers'. Ironically, these cases - which are sporadic and famous precisely for their uniqueness - would seem to keep faith in the meritocracy alive.

"Did you see? The one who wants to, can." In this simple way, without us realizing, we overlook the fact that Roberto and Marta had to make an infinitely greater effort than several of their classmates, to achieve more or less the same thing. For 'equal effort-equal reward' try the office next door.

Another issue with those stories that excite us so much in TED talks, for example, is the enormous bias that is activated when we take exceptional cases as if they were indicators of the way the world works. Because while we celebrate that 'whoever tried succeeded' and then 'it's enough to try', we lose view of the other thousands who tried but didn't succeed.

There is an anecdote from the Second World War that helps quite a bit to understand how this bias, known as 'survivor bias', works. At the height of the fighting, the Allies hired a team of experts to tell them which parts of the planes should be reinforced. The idea was to make them better able to withstand artillery attacks, but without the enormous expense of reinforcing the entire plane. The proposal of the military commanders was to reinforce them in the areas where the returning planes did the most damage. But the experts thought otherwise, because those were the impacts on the returning planes. In other words, those parts were not representative of the most vulnerable, but quite the opposite.

To think that Maria - hashtag the entrepreneurial - is representative of a victory of the meritocracy is not to look at the fact that we have to reinforce the plane where there is no impact, because those are the planes that do not return. 


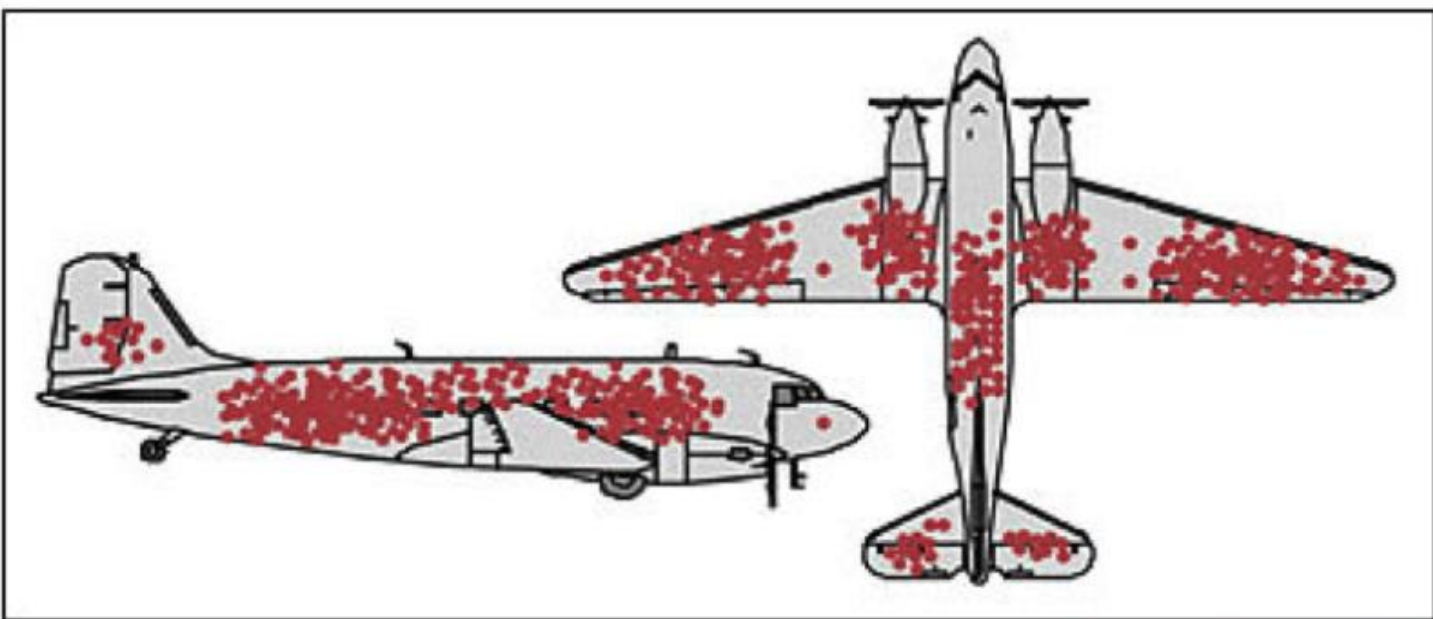

Credit: CameronMoll

\section{What you inherit you don't steal. Nor is it merit.}

Few would dare to say that everything depends on effort in a slave-owning or medieval society. Meritocracy is supposed to appear when we have 'freedom' and can 'choose'. When even the boy from the neighbourhood can make it 'out of nothing'. If we all have the freedom to work, invest, create a company and be successful, the results depend entirely on us. Capitalism, free market, the individual in power.

Meritocracy is one of the promises of liberal capitalism par excellence. But there is a problem when we identify freedom with possibility. Because having freedom to do things is, of course, a very important condition for 'being able to' do them, but it is not necessarily enough. It is also necessary to have the 'opportunity'. And however much freedom is guaranteed, in unequal societies (as are basically all societies) opportunities are not distributed among all with the same uniformity and regularity.

Now, we could go on talking about this for a long time, but it is only by looking at the data that we can answer whether or not the key conditions are met to know whether different achievements reflect different individual efforts or whether they actually reflect different opportunities. This is when we should go down to the streets of evidence and look at whether socio-economic inequality is explained by the 
Journal of Science, Humanities and Arts

May 2020

Volume 7, Issue 3

action of the meritocratic mechanism, whether the market really does uniformly compensate equivalent efforts, and whether competition is on an equal footing. We must analyse whether the achievements of each person are exclusively associated with their individual behaviour and performance or whether, on the other hand, there is an independent conditioning of the actions of individuals.

Some useful approaches to the question are obtained through analyses of social mobility, social inheritance and the intergenerational transmission of poverty. Social mobility has to do with the possibilities of accessing other class positions being equal for all individuals, regardless of their class of origin. Its counterpart, social inheritance, means that people's life chances are restricted or favoured by their socio-economic background.

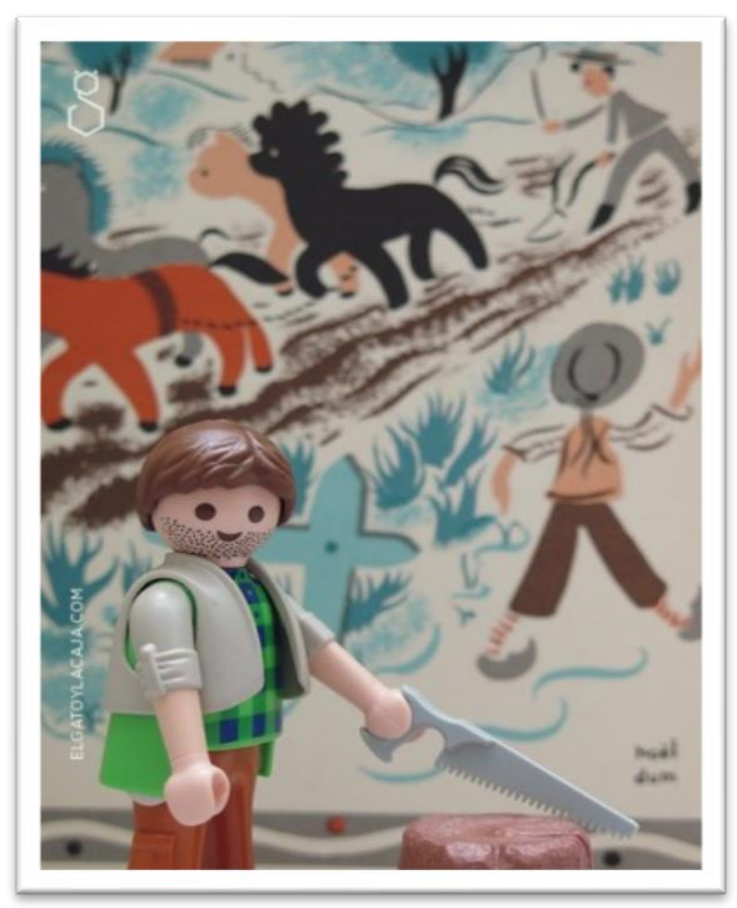

In a society with effective equality of opportunity, where only individual virtues and particular efforts define socioeconomic achievements, everyone has equal possibilities to place themselves in any social class, depending on themselves. Therefore we should find, in each social stratum, people of multiple origins, without any predominant trend. If, however, we find a high correlation between social origin and achievements in adult life, we have a strong indication that inequalities do not have much to do with meritocracy.

Measuring the relationship between socio-economic achievement and 'merit' and associating them with social background is quite complicated, mainly because of the difficulty of having data on the same individual throughout his life. In order to find out 
the 'social origin' of people, information is needed from the past, or data from the present of those people who have not yet entered the labour market, who are still dependent on their families. But then we will not yet be able to know what their achievements will be. What we can do, then, is ask the question a little bit earlier and ask ourselves not only if society rewards merit equally, but something even more delicate: does doing what is considered 'merit to be rewarded' demand the same effort from all of us?

\section{Grabbing the shovel}

One indicator that is widely accepted as a 'reflection of merit' is educational level: training. If we found that social heritage interferes with the acquisition of these credits, the meritocratic scheme would be broken before we go out to compete in the market.

In an academic article some years ago, together with my colleague Marcos Andrada, we proposed a way of looking at the association between educational achievement and socio-economic background with data from household surveys. We selected young people aged 18 to 25 years who were still living in their parents' home as 'children', in order to simultaneously observe their educational achievements and their socio-economic background. Obviously, this has its limitations (as with all measurements): because the socio-economic situation of the household at the time the data were taken is not necessarily stable over time. In other words, it is not necessarily identical to the 'origin', to the socio-economic conditions that our young person experienced during the years of educational training. But, nevertheless, it gives us an approximation.

In these boys and girls we look, on the one side, at the maximum level of education achieved, and on the other, at the income per person in their home. We ordered them into 5 groups, from those with the least to those with the most income, which we will call 'quintiles'. In each quintile we observe what percentage reached each educational level. At the time, the data we looked at for 2011 was as conclusive as the data we can see in 2017 (that is, with data from the The Argentinean National Institute of Statistics and Censuses - INDEC - not being questioned). 
Journal of Science, Humanities and Arts

2017: composition of educational attainment of young people in each family's per capita income quintile

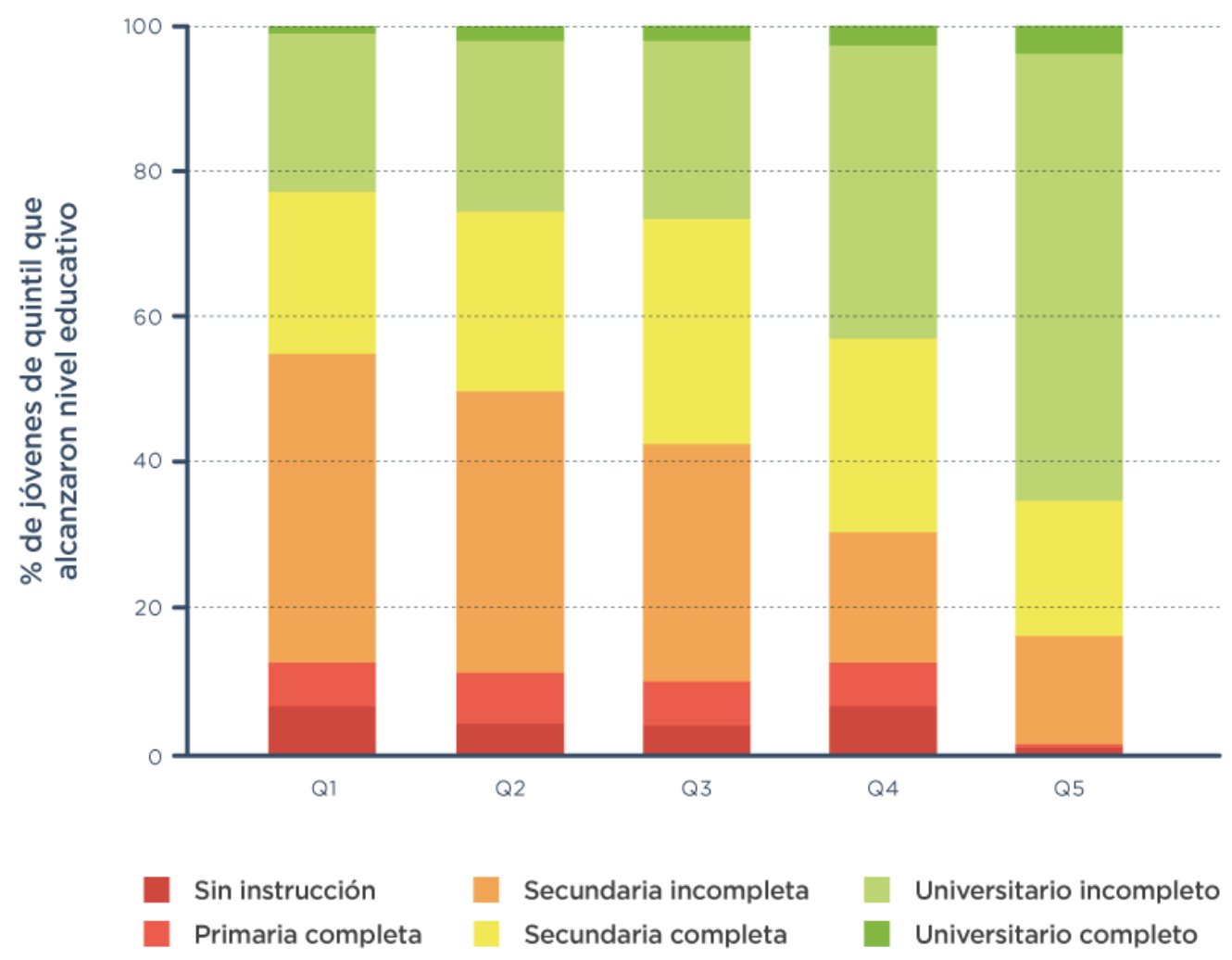

The bars represent the groups (quintile), from the poorest to the richest, from left to right. In each column (i.e. quintile) the red and orange area represents low educational achievement (up to incomplete secondary) and the green area represents high achievement (access to university). We can see how red and orange decrease from left to right (from poor to rich) and with green the opposite happens.

The data indicate that modest educational attainment predominates in lowerincome families, while the higher household income, the higher the level of education completed. A comparison of the extreme values of the socio-economic distribution (the first and last quintile) shows the crudest expression of inequality in 
educational achievement: most of the lower-income young people have not even completed secondary education, while most of those with the greatest gains in the distribution of income have had access to, and in some cases even managed to complete, university education.

What the association could mean is that the educational level reached is a variable that depends, in some way, on the family's socioeconomic level. In other words, if the association between them is due to a conditioning relationship, it is neither symmetric nor is 'social origin' expected to be the dependent variable: there would be no reason why the educational credits of young children, who are not the economic breadwinners of their homes, should be the ones that explain the income levels of their families. Now, determining how income levels affect (if at all) educational attainment implies another type of theoretical and empirical approach. In some cases, even with qualitative studies that, for example, include in-depth interviews and follow-up of specific cases.

Among various studies that determine specific conditioning factors of educational performance and others that analyze the interaction of such conditioning factors according to social origin, it has been found that social origin can condition the educational process in various ways: according to the symbolic and cultural resources of families; the differential social capital of the contexts of socialization of children and young people; the incidence of health and nutritional problems, and of overcrowded contexts; the imperative in some cases of working at an early age; the economic resources to support the educational process (such as access to books or private classes); and even how the realities of origin and their stability affect the expectations and, therefore, the very aims of young people. Although some authors consider some factors more relevant than others to explain conditioning in each time and place or as a general trend, there is not much controversy that conditioning as such exists in unequal societies. 


\section{The meritocracy, the hangman of the meritocracy}

If unequal conditions translate into unequal opportunities, it is impossible to implement a meritocracy. Therefore, the more unequal a society is and the more it depends on the budget for access to education, health and culture (among many other factors), the less 'equal opportunities' will be fulfilled and the more weight will be given to circumstances that we did not choose.

In the end it turns out that meritocracy is an ideal by definition unreachable because, if it necessarily produces inequality by rewarding different efforts, it is itself that generates the conditions for competition, in the future, to be unequal.

Collectivizing and universalizing opportunities, again and again, reducing inequality and evening out the playing field from time to time, not only at the beginning but throughout one's life, is in the end much more consistent with meritocracy than the idea of leaving it to each individual to fend for himself. If we really want to push towards a fairer society, perhaps we should talk less about meritocracy and more about equity (i.e., compensation for disadvantages and inequalities), to contribute as much as possible to ensuring that no one really gets less than 'what they deserve'. 


\section{REFERENCES}

Erzsébet Bukodi \& John H. Goldthorpe Decomposing 'Social Origins': The Effects of Parents' Class, Status, and Education on the Educational Attainment of Their Children. John Goldthorpe and Michelle Jackson. EDUCATION-BASED MERITOCRACY: THE BARRIERS TO ITS REALISATION.

BINSTOCK, G., \& CERRUTTI, M. (2005). Carreras Truncadas: El abandono escolar en el nivel medio en la Argentina. Buenos Aires, Argentina: UNICEF.

PAES DE BARROS, R., FERREIRA, F., MOLINAS VEGA, J., \& SAAVEDRA CHANDUVI, J. (2008). Midiendo la Desigualdad de Oportunidades en América Latina y el Caribe. Washington, EE.UU: Banco Mundial.

BLANCO, S., \& CUSATO, R. (2005). Desigualdades educativas en América Latina: todos somos responsables. Santiago de Chile: UNESCO.

MÉNDEZ, M. L., \& GAYO, M. (2007). El perfil de un debate: movilidad y meritocracia. Contribución al estudio de las sociedades latinoamericanas. En F. Rolando, Estratificación y movilidad social en América Latina: transformaciones estructurales de un cuarto de siglo (págs. 121-161). Santiago de Chile: LOM Ediciones.

MINOLDO y ANDRADA (2013). Herencia social y logros educativos en Argentina ¿Meritocracia o herencia social?. Revista Complutense de Educación.

Gutiérrez, A. B. (2005). Pobre', como siempre: estrategias de reproducción social en la pobreza: un estudio de caso. Ferreyra.

BOURDIEU (1997) "Capital cultural, escuela y espacio social". Siglo Veintiuno; México.

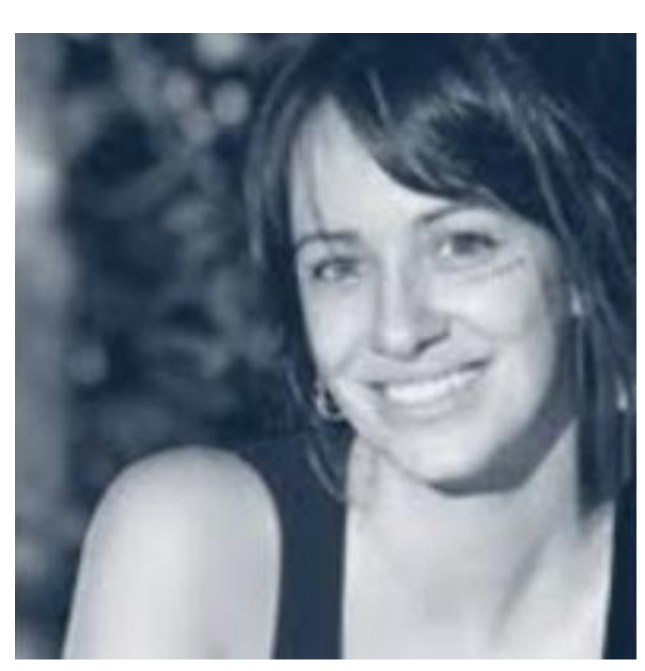

\section{About the author:}

Sol Minoldo is a Sociologist, Cordoba and doctor of those who do not cure. An amateur in photography and chocolate ice cream. 